\title{
THE PREVALENCE OF URINARY TRACT INFECTIONS IN PREGNANCY AND IMPLICATIONS ON FOETAL DEVELOPMENT
}

\author{
OTILIA MICLE ${ }^{\#}$, LIANA ANTAL, PETRONELA NAGHI, OTILIA ȚICA, DANA CARMEN \\ ZAHA*, MIHAELA MIRELA ZDRÎNCA, LUCIANA DOBJANCHI, MONICA SABĂU\#, \\ MARIANA MUREȘAN
}

University of Oradea, Faculty of Medicine and Pharmacy, $1^{\text {st }}$ December Street, Oradea, 410073, Bihor, Romania

*corresponding author: danaczaha@gmail.com

${ }^{\#}$ Authors with equal contribution.

Manuscript received: October 2019

\begin{abstract}
Urinary tract infection is one of the common infections in the pregnancy causing disturbances in the foetal growing and development. This study was conducted to determine the distribution and antimicrobial susceptibility of uropathogens in the pregnant women attending County Emergency Clinical Hospital Oradea, Romania as well as to determine the potential effect of foetal development and/or birth defects. Clean catch midstream urine was collected from 427 patients of the age ranging from 13 to 44 years. Urine specimens were chemically analysed (by dipstick) and microscopy, and then cultured in laboratory. After identification, antimicrobial susceptibility was performed on all isolated bacteria by Kirby Bauer's disc diffusion method and the multiple antibiotic resistance (MAR) index of each antibiotic was calculated. The prevalence of ITU was $65.33 \%$ in our patients and it was significantly higher in third trimester of the pregnancy. Gram negative bacteria (90.11\%) were found in higher prevalence than Gram positive $(9.88 \%)$. Escherichia coli $(76.31 \%)$ was the most prevalent isolate. All isolated strains have shown good susceptibilities rates. We found association between UTIs and mean birth weight and preterm birth.
\end{abstract}

\section{Rezumat}

Infecția tractului urinar este una dintre cele mai obișnuite în sarcină determinând tulburări în creșterea și dezvoltarea fătului. Acest studiu a fost realizat pentru a evalua distribuția și sensibilitatea antimicrobiană a uropatogenilor la femei însărcinate internate la Spitalul Clinic Județean de Urgență Oradea, precum și pentru a determina efectul potențial asupra dezvoltării fetale. Urina a fost recoltată din jetul mijlociu de la 427 de paciente cu vârsta cuprinsă între 13 și 44 de ani. Probele au fost analizate chimic și microscopic, apoi cultivate în laborator. După identificare, sensibilitatea antimicrobiană a tulpinilor izolate a fost realizată prin metoda difuzimetrică (Kirby Bauer) și a fost calculat indicele de rezistență multiplă la antibiotice (MAR) al fiecărui antibiotic. Prevalența infecției urinare a fost de $65,33 \%$ și a fost semnificativ mai mare în al treilea trimestru de sarcină. Prevalența bacterilor Gram negative $(90,11 \%)$ a fost mai mare decât a celor Gram pozitive $(9,88 \%)$. Escherichia coli $(76,31 \%)$ a fost cel mai frecvent izolat. Toate tulpinile izolate au prezentat rate de susceptibilitate bune. Prezența infecției urinare a fost asociată cu greutatea medie la naștere și nașterea prematură.

Keywords: pregnancy, urinary infection, foetal development

\section{Introduction}

Urinary tract infections are a very common pathology and recorded at any age, regardless of gender, and are associated with significant morbidity and mortality with considerable social and economic impact. UTIs are described as bacteriuria with urinary symptoms. Asymptomatic bacteriuria (ASB) is a common finding in many populations, including healthy women and persons with underlying urologic abnormalities. Considering the benefits of maternal antibiotic treatment and foetal effects pregnant women should be screened and treated for ASB and the treatment of is different for uncomplicated and complicated ITUs [1]. In women, however, it is more common than in men, explained by the shorter urethra, closer proximity of the anus with vagina, and pathogen entry facilitated by sexual activity [2]. In the perinatal period, urinary tract infections are a relatively frequent cause of morbidity, occurring in approximately one-third of pregnant women [3] and after anaemia, are the second common complications in pregnant women [4].

Pregnancy is a physiological state, which causes numerous hormonal and mechanical changes in the body. During this period, the renal system is the site were anatomic and functional changes occur such as enlargement and dilation of the kidneys and urinary collecting system. Progesterone hormone causes relaxation of the ureters smooth muscle, which results in dilation, decreases bladder tone, increasing the residual volume, the risk of urinary stasis and vesicoureteral reflux [5]. In the same time, during pregnancy, the physiological increase in plasma volume and decrease in urine 
concentration develop glycosuria and aminoaciduria that may facilitate bacterial growth in areas of urinary stasis $[6,7]$. All these factors can help to increase susceptibility to urinary tract infections. Untreated they may complicate pregnancy with anaemia, hypertension, preeclampsia, premature birth, low birth weight $[8,9]$. In the same time there are research papers which underlined that uncomplicated urinary tract infections have been associated with adverse pregnancy outcomes such as intrauterine growth restriction and preterm labour [10-12].

The spectrum of bacteria and the antimicrobial susceptibility data of UTI-causing microorganisms changes from time to time and from an area to another, but the most commonly encountered microorganisms are Gram-negative bacteria including Escherichia coli, Citrobacter spp., Enterobacter aerogenes, Pseudomonas aeruginosa, Proteus spp. and Klebsiella spp. Multidrug resistance is difficult to solve under the modest results regarding the discovery of new antibiotics; maybe the solution could be found in some plant extracts [13-15]. Moreover, antibiotics and analgesics are the most prescribed drugs in a hospital and most UTIs are treated empirically. The criteria for the selection of antimicrobial agents is based on the most likely pathogen and its expected resistance pattern in that area. Therefore, the periodic monitoring of etiologic agents of UTI and their resistance pattern in the community is mandatory $[16,17]$. Choice of antimicrobials during pregnancy must be safety for both the mother and the foetus because most antimicrobials cross the placenta.

The prevalence of asymptomatic bacteriuria (ASB) in pregnant women is about $2-10 \%$ [18] and about $20 \%$ to $35 \%$ of pregnant women with ASB, without treatment, will develop a symptomatic urinary tract infection (UTI), including pyelonephritis [19, 20]. However, Kazemier et al. in 2015 suggested a lower rate of pyelonephritis in women with untreated asymptomatic bacteriuria. It should be noted that only low-risk single pregnancy, without diabetes or abnormalities of the urinary tract were included in this study and is not sure that these results are can be generalized [21].

The purpose of the study was to evaluate the type of bacterial aetiology that causes urinary tract infections, the antibiotic susceptibility pattern in pregnant women and if there are correlations between asymptomatic bacteriuria and adverse maternal and neonates' outcomes.

\section{Materials and Methods}

Our study was carried out on pregnant outpatients and inpatients at the Emergency County Clinical Hospital Oradea, Romania for two years from July 2011 to January 2019. The urine samples of 427 pregnant women who had no clinical evidence of urinary tract infection were included in this study. The patients on antibiotic therapy were excluded from the study.

The research was performed according the WMA Declaration of Ethical Helsinki - Medical Research Involving Human Principles for Subjects and it was also approved by the Ethics Commission of the Council of Medicine and Pharmacy Faculty, University of Oradea, Oradea and Emergency County Clinical Hospital Oradea, Romania.

Clean catch midstream urine was collected from each patient into a sterile urine universal container which was labelled, transported to the laboratory, and analysed within 2 hours. All patients were well instructed on how to collect sample aseptically prior to sample collection to avoid contamination. Urine specimens were chemically analysed (by dipstick) and microscopy, and then cultured in laboratory. Test strips were performed for rapid determination of $\mathrm{pH}$ value and density in urine, blood, urobilinogen, bilirubin, protein, nitrite, ketones, ascorbic acid, glucose. Then wet film of urine deposit is evaluated for WBCs, RBCs, cells and crystals. Pyuria can be detected either by microscopic examination (defined as $\geq 10$ leukocytes $/ \mathrm{mm}^{3}$ ), or by dipstick leukocyte esterase and nitrite test.

Urine culture was performed using a calibrated loop to inoculate $10 \mu \mathrm{L}$ of un-centrifuged urine on blood, CLED (cysteine-, lactose- and electrolyte-deficient) agar and on Levine agar and incubated overnight at $37^{\circ} \mathrm{C}$ and for $48 \mathrm{~h}$ in negative cases. The number of isolated bacterial colonies was multiplied by 1000 for the estimation of bacterial load $/ \mathrm{mL}$ of the urine sample. A specimen was considered positive for UTI if an organism was cultured at a concentration of $\geq 10^{5}$ colony forming units $(\mathrm{CFU}) / \mathrm{mL}$ or when an organism was cultured at a concentration of $10^{4} \mathrm{CFU} / \mathrm{mL}$ (low bacterial count) and leukocyturia \pm positive nitrite test. The number of bacteria is estimated and interpreted as follows: a single bacterial species from the urine sample at a concentration of $1 \times 10^{5} \mathrm{CFU} / \mathrm{mL}$ or more is significant for urinary tract infections; less than $1 \times 10^{4}$ $\mathrm{CFU} / \mathrm{ml}$, polymicrobic are considered as contamination; less than $1 \times 10^{3} \mathrm{CFU} / \mathrm{mL}$ negative for urinary tract infections.

By using dipstick, we assessed for the presence of urinary nitrite. A positive test indicates the presence of Gram-negative bacteria in urine, while a negative test is the product of low count bacteriuria or bacterial species that lack the ability to reduce nitrate to nitrite (mostly Gram-positive bacteria) or negative for any bacteria.

Identification of bacterial isolates was provided by their cultural and biochemical characteristics. The morphological characteristics, size and arrangement of the purified bacterial isolates were carried out by examination of Gram stained smears (Gram-positive or Gram-negative, cocci, bacilli, Candida spp etc.). The identification of isolates was performed by classical methods (cultivation, biochemical properties) and 
FARMACIA, 2020, Vol. 68, 3

antibiotic sensitivity by Kirby-Bauer disk diffusion method using standard inoculum adjusted to 0.5 McFarland. The isolate was classified as susceptible, intermediate or resistant based on the Clinical Laboratory Standards Institute (CLSI) criteria [22]. The standard antibiotic discs were used for the antibiogram as follows: ampicillin (AMP), amoxicillin (AMX), ampicillin + sulbactam (SAM), amoxicillin + clavulanic acid (AMC), ciprofloxacin (CIP), ofloxacin (OFX), norfloxacin (NOR), amikacin $(\mathrm{AK})$, gentamycin $(\mathrm{CN})$, ceftriaxone (CRO), ceftazidime (CAZ), cefuroxime (CXM), cefoperazone (CEP), erythromycin (ERY), azithromycin (AZM), clarithromycin (CLR), penicillin (P).

Standard strains E. coli ATCC 25922, S. aureus ATCC 29213, P. aeruginosa ATCC 27853, E. faecalis ATCC 29212 were used as quality control strains to check the quality of culture media, and antimicrobial cards and disks according to CLSI [22].

The multiple antibiotic resistance indices (MARI) were calculated by the method described by Tambekar et al. [23].

Socio-demographic characteristics, clinical and laboratory data were extracted from the hospital computer system and medical records of patients admitted in our hospital, resulting in a number of 427 patients of different ages presenting urinary symptoms (dysuria, suprapubic pain and/or fever at presentation) and significant microbial growth. We also noted birth weight and gestational age, Apgar score at 1 and 5 minutes about new-born infants corresponding those 427 patients.

Statistical analyses

All statistical analyses were performed using software SPSS 24. Results are presented as mean \pm standard deviation (SD) for numeric variables or percentages. Continuous normal distribution variables were reported as mean and SD. The categorical variables were reported as percentages. Continuous variables were analysed and expressed by mean and standard and/or median deviation. The correlation degree (r) between the studied parameters were evaluated by calculating the Pearson correlation coefficient. A $p<0.05$ limit value was considered statistically significant. Intergroup comparisons were performed using either the Chisquare test or the one-way ANOVA method to see to what extent the differences between the independent and dependent variables are statistically significant. Later, we tested the assumptions (controlling the independent variables) using the multinomial logistic regression method to identify the direct effects and potential mistaken effects. The statistical analysis was conducted in accordance with the guidelines on reporting statistical data in medical journals.

The research was performed according the WMA Declaration of Ethical Helsinki - Medical Research Involving Human Principles for Subjects and it was also approved by the Ethics Commission of the Council of Medicine and Pharmacy Faculty, University of Oradea, Oradea and Emergency County Clinical Hospital Oradea, Romania.

\section{Results and Discussion}

The age of patients included in the study ranged from 13 to 44 years and the mean age is $24.91 \pm 0.34$ as seen in Figure 1. From a total of 427 patients that gave birth, $78.1 \%$ had a c-section, less than a quarter $(13.1 \%)$ had a vaginal delivery and only $8.8 \%$ had a non-assisted natural birth. In $98.82 \%$ of the cases we observed a single pregnancy, in $1 \%$ of the case a twin pregnancy and triple pregnancy was found in $0.23 \%$ of the cases resulting 433 new-born infants.

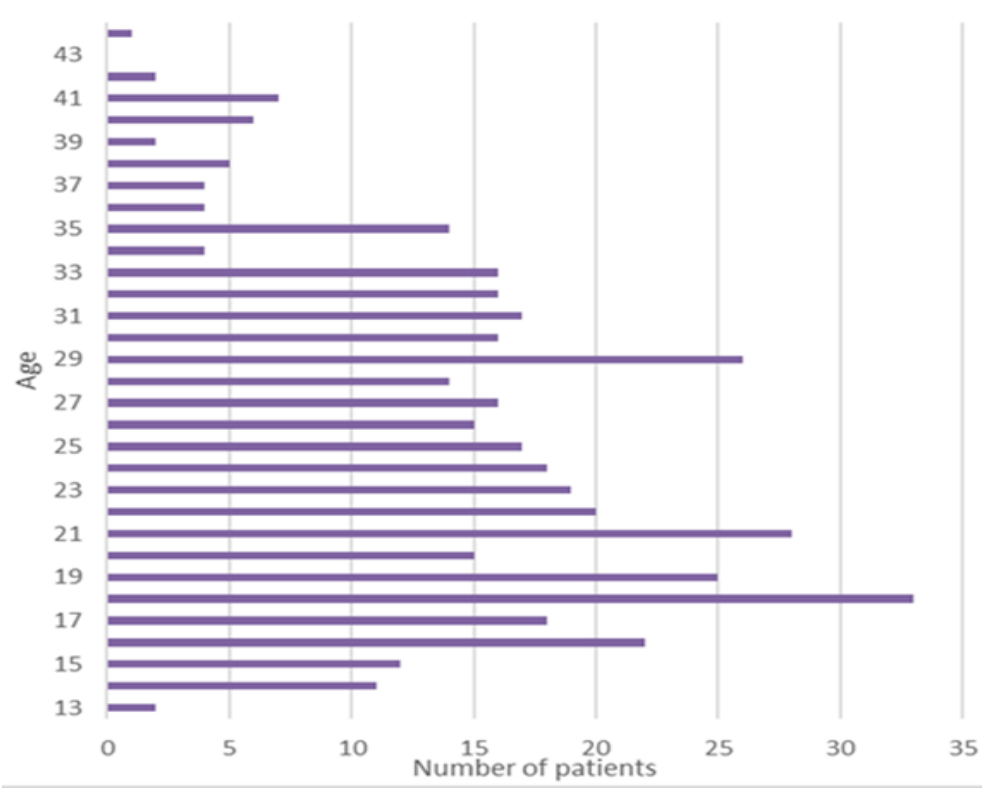

Figure 1.

Age of patients 
We found in our study a higher prevalence of UTIs $(65.33 \%)$ presenting significant changes by trimesters, it doubles in the second trimester and is six times higher in the third versus the first trimester (Figure 2). By evaluating the results of the urine test by dipstick it results that a number of $279(65.33 \%)$ presented pyuria or they were positive for leukocyte and nitrite test.

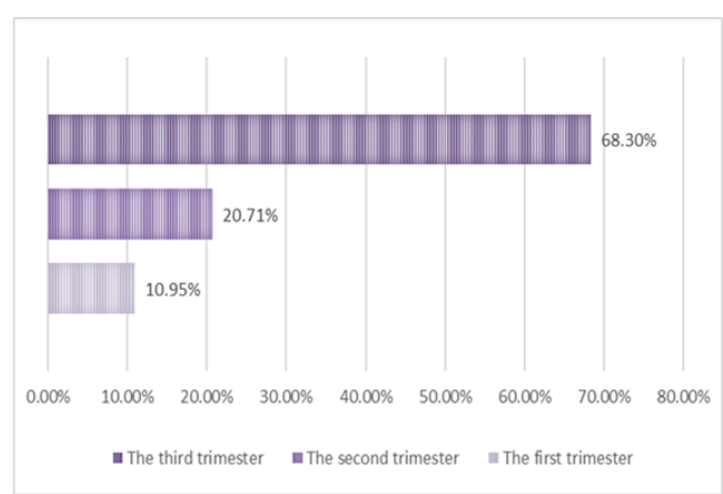

Figure 2.

The incidence of bacteriuria during trimesters

In seven urine specimens, more than one species of bacteria was isolated. A number of 43 of 60 strains of Proteus spp. were Proteus mirabilis, 30 out of 38 strains of Enterococcus spp. were Enterococcus faecalis, and 25 out of 32 strains of Klebsiella spp. were Klebsiella pneumoniae.
The main purpose of urine examination was the identification and quantification of bacteria, mainly uropathogens in order to give appropriate treatment. The most frequent bacteria identified in our study was E. coli $(76.31 \%)$ followed by Proteus spp. (9\%), Enterococcus spp. (5.7\%) and Klebsiella spp. (4.8\%) as can be seen in Figure 3.

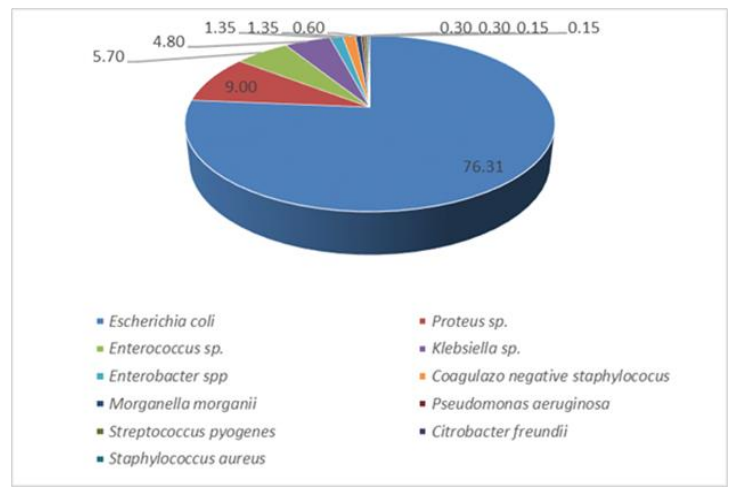

Figure 3.

The isolated strains from urine specimens

E. coli, the most frequently isolated, proved a good sensitivity to almost all the tested antimicrobials except for ampicillin and amoxicillin, as can be seen in the Figure 4. A percentage of 6.48 of $E$. coli strains were ESBL producing.

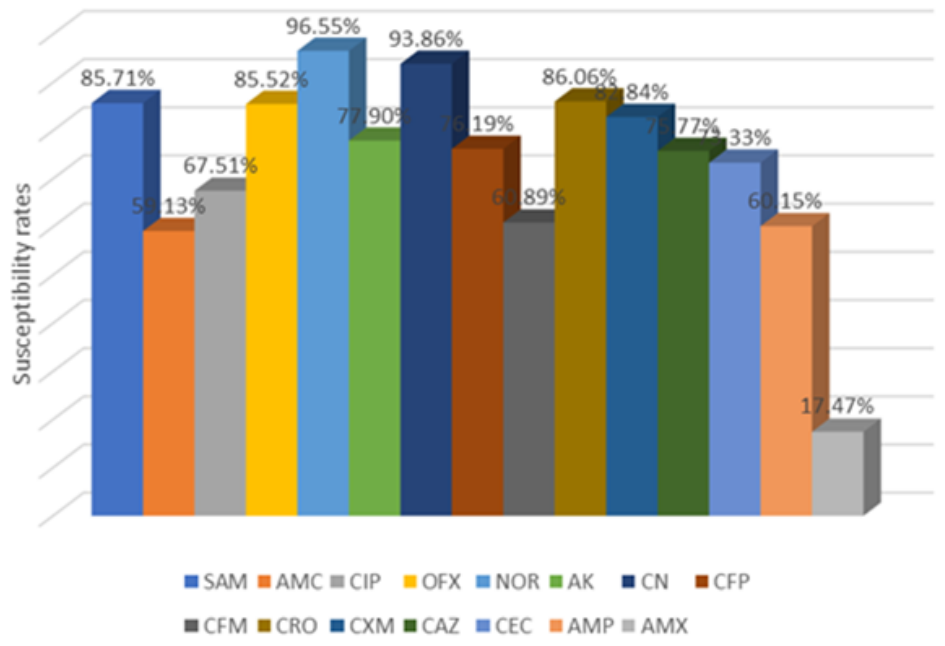

Figure 4.

Susceptibility rates of $E$. coli strains to antibiotics

The second most frequently isolated agent Proteus spp., was more susceptible to antibiotics compared to $E$. coli strains, sensitivity rates being over $70 \%$, except for cefixime $(65 \%)$, ceftazidime $(67.85 \%)$, ampicillin $(56.52 \%)$ and amoxicillin (38.88\%). A number of 4 Proteus spp. strains $(6.66 \%)$ was ESBL producing (Figure 5).

The most isolated gram-positive bacteria belongs to Enterococcus spp., the most frequently isolated being E. faecalis otherwise the third etiological agent of the UTIs. These isolates showed a good level of sensitivity to gentamycin (100\%), ciprofloxacin (80\%), penicillin $(72.41 \%)$, but were resistant to erythromycin $(34.37 \%)$. A number of 8 isolated strains were $E$. faecium showing sensitivity only to linezolid and tetracycline. Synergistic effect of GN as an adjunct to systemic penicillin, ampicillin, vancomycin treatment was preserved in $86.9 \%$ of the Enterococcus strains tested (Figure 6). 


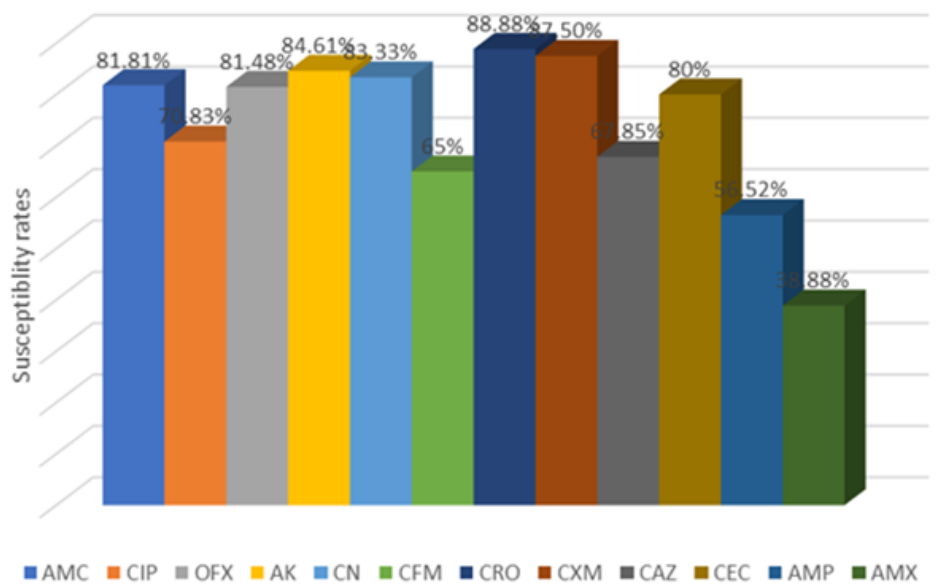

Figure 5.

Susceptibility rates of Proteus spp strains to antibiotics

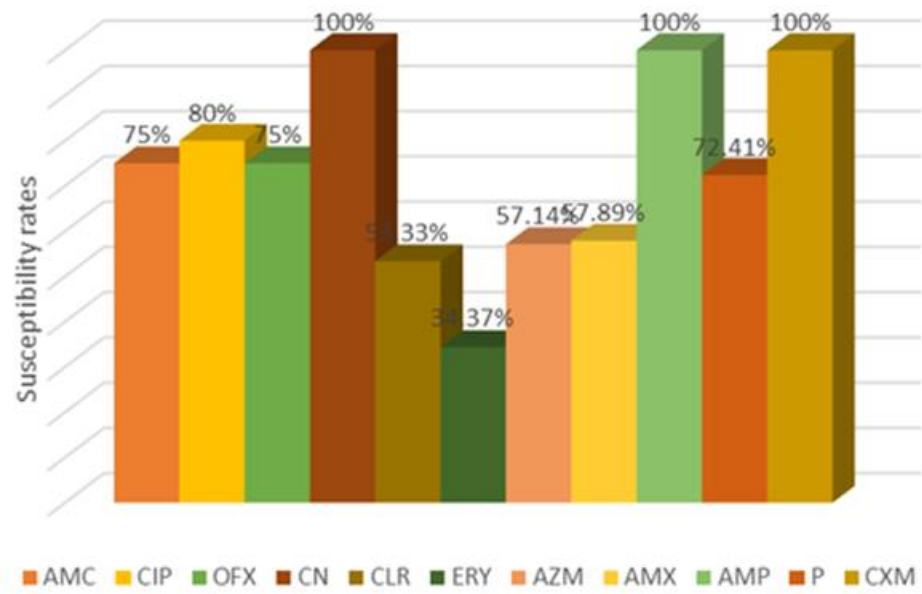

Figure 6.

Susceptibility rates of Enterococcus spp strains to antibiotics

Regarding the MAR index (Figure 7), the highest was found for AMX (0.46) followed by AZM (0.4) indicating that these antibiotics were highly resistant among almost tested uropathogens. In the same time, the lowest MAR index was found for CFP, AK, OFX, CXM, AMC, GEN, NOR, CRO: 0.043, 0.045, $0.048,0.051,0.052,0.054$ and 0.057 respectively, indicating the highest sensitivity against uropathogens.

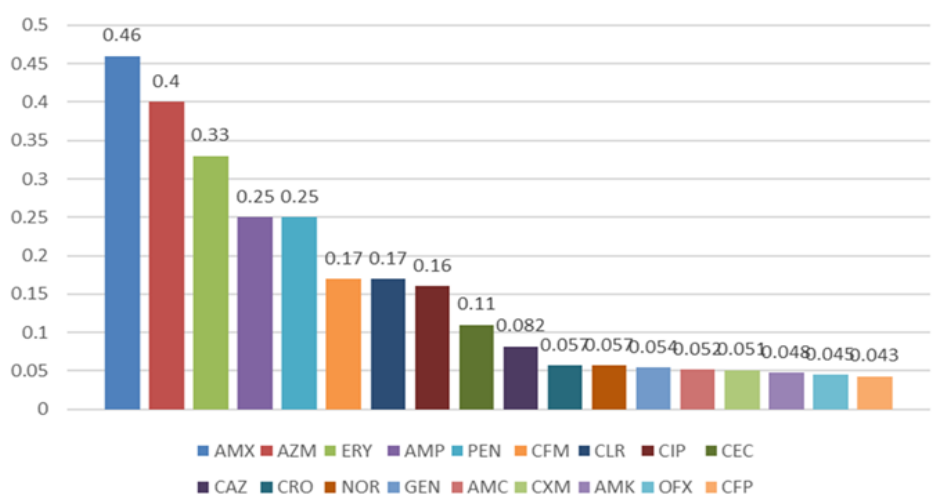

Figure 7.

Overall resistance of all isolated uropathogens against tested antibiotics

Of 433 new-born infants born to mothers with UTI during pregnancy, 249 (57.50\%) were boys and 184
(42.29\%) girls. There is an obvious association between UTI and mean birth weight mean and preterm birth 
as can be seen in Table I ( $\mathrm{p}<0.05)$. The proportion of preterm births (10.4\% vs $9.1 \%)$ was higher in the group of mothers with UTIs. The analysis from birth outcomes has shown that the mean gestational age was shorter in new-born infants from mothers with UTI compared to mothers without UTI (considered as a reference group). The mean birth weight was slightly lower in the babies of mothers with UTI but without statistical significance, as well as the APGAR score.

Table I

The main birth outcomes of new-born infants (born to mothers with urinary tract infections)

\begin{tabular}{|l|c|c|c|}
\hline & $\begin{array}{c}\text { UTI group } \\
\text { (Mean } \pm \text { SD) }\end{array}$ & $\begin{array}{c}\text { No-UTI group } \\
\text { (Mean } \pm \text { SD) }\end{array}$ & p value \\
\hline Gestational age (weeks) \\
\hline $\begin{array}{l}\text { Female } \\
\text { Male }\end{array}$ & $36.9 \pm 2.9$ & $38.5 \pm 2.2$ & 0.95 \\
\hline Birth weight $(\mathrm{g})$ & $39.1 \pm 1.1$ & \\
\hline Female & $2765 \pm 430$ & $3456 \pm 486$ & 0.008 \\
Male & $3145 \pm 510$ & $3580 \pm 478$ & \\
\hline APGAR score at 1 min \\
\hline Female & $8.22 \pm 0.98$ & $8.66 \pm 1.24$ & 0.94 \\
Male & $8.97 \pm 1.01$ & $8.78 \pm 1.21$ & \\
\hline APGAR score at 5 min \\
\hline Female & $8.95 \pm 1.05$ & $9.69 \pm 0.28$ & 0.95 \\
Male & $9.14 \pm 0.76$ & $9.78 \pm 0.21$ & \\
\hline Preterm birth (number) \\
\hline Female & 98 & 86 & 0.040 \\
Male & 157 & 92 & \\
\hline Low birth weight (number) \\
\hline Female & 121 & 63 & 0.24 \\
Male & 146 & 10 & \\
\hline
\end{tabular}

Symptomatic and asymptomatic urinary infections in pregnant women are associated with risks to both the foetus and the mother such as complications of urinary infection and preterm birth, low birth weight, and increased perinatal mortality [24, 25]. In order to identify the relationship between the bacteria that caused urinary tract infection as well as gestational age in female patients and their age we performed a bivariate analysis. We can observe a high positive correlation using a bivariate analysis between the bacteriuria and the pregnant women's age in the $3^{\text {rd }}$ trimester $(\mathrm{p}=0.000)$.

We assessed through ought a logistic regression analysis variable such as maternal age, time of infection (the gestational age when the infection occurred) and the bacteria associated with the infection; the ones with significant statistical value were considered as candidates for multivariate logistic regression. The maternal age is a risk factor for urinary tract infection controlling for the gestational age and time of infection.

We found in our study a higher prevalence of ITUs presenting significant changes by trimesters. It is higher in the third versus the first trimester, opposite to conclusion of a study conducted by Ailes et al., UTI diagnoses were most frequent during the first trimester of pregnancy (41.0\% of UTIs) and least frequent in the third [26]. Similar aspects regarding the aetiology, but also the resistance to antibiotics have been demonstrated in other studies [15]. The extensive uses of antimicrobial agents and development of MDR strains include the shift in hospital acquired pathogens from easily treatable towards more resistant organisms and these resistant organisms' spread is no longer limited to the hospital environment [27]. The high MAR index of the isolates indicates previous exposure to a specific antibiotic and development of resistance to commonly prescribed antibiotics. Attention also needs to be paid on effective infection control and prevention of spreading of among individuals. Using a logistic regression (multivariate analysis) we could prove the association between the bacteriuria in third trimester and mother's age as confirming other studies [24].

\section{Conclusions}

The prevalence of ITU was significantly higher and especially in third trimester of the pregnancy. Gram negative bacteria were found in higher prevalence than Gram positive and all isolated strains have shown good susceptibilities rates. We found association between UTIs and mean birth weight and preterm birth and mother's age. The results of our study show a high prevalence of urinary tract infection with a moderate degree of neonatal impairment, which requires careful and sustained monitoring of pregnancy.

\section{Conflict of interest}

The authors declare no conflict of interest.

\section{References}

1. Bonkat G, Pickard R, Bartoletti R, Bruyère F, Geerlings SE, Wagenlehner F, Wullt B, Cai T, Köves B, Pilatz A, Pradere B, Veeratterapillay R, EAU Guidelines on Urological Infections, European Association of Urology, 2017.

2. Tadesse E, Teshome M, Merid Y, Kibret B, Shimelis $\mathrm{T}$, Asymptomatic urinary tract infection among pregnant women attending the antenatal clinic of Hawassa Referral Hospital, Southern Ethiopia. BMC Res Notes., 2014; 7: 1-5.

3. Celen S, Oruç AS, Karayalçin R, Saygan S, Unlü S, Polat B, Danişman N, Asymptomatic bacteriuria and antibacterial susceptibility patterns in an obstetric population. ISRN Obstet Gynaecol., 2011; 2011: 1-4.

4. Mittal P, Wing DA, Urinary tract infections in pregnancy. ClinPerinatol., 2005; 32(3): 749-764.

5. Giraldo PC, Araújo ED, Junior JE, Amaral RLGD, Passos MRL, Gonçalves AK, The Prevalence of urogenital infections in pregnant women experiencing preterm and full-term labor. Infect Dis Obstet Gynecol., 2012; 2012: 1-4.

6. Petca RC, Popescu RI, Mareș C, Petca A, Mehedințu C, Sandu I, Măruan N, Antibiotic resistance profile of common uropathogens implicated in urinary 
FARMACIA, 2020, Vol. 68, 3

tract infections in Romania. Farmacia, 2019; 67(6): 994-1004.

7. Jeyabalan A, Lain KY, Anatomic and functional changes of the upper urinary tract during pregnancy. Urol Clin North Am., 2007; 34: 1-6.

8. Matuszkiewicz-Rowińska J, Małyszko J, Wieliczko $\mathrm{M}$, Urinary tract infections in pregnancy: old and new unresolved diagnostic and therapeutic problems. Arch Med Sci., 2015; 11(1): 67-77.

9. Cheesebrough M, District tropical disease laboratory. $2^{\text {nd }}$ ed: Cambridge University Press; 2005.

10. Schieve LA, Handler A, Hershow R, Persky V, Davis F, Urinary tract infection during pregnancy: its association with maternal morbidity and perinatal outcome. Am J Public Health., 1994; 84(3): 405-410.

11. Delzell JEJr, Lefevre ML, Urinary tract infections during pregnancy. Am Fam Physician., 2000; 61: 713-721.

12. Emamghorashi F, Mahmoodi N, Tagarod Z, Heydari ST, Maternal urinary tract infection as a risk factor for neonatal urinary tract infection. Iran J Kidney Dis., 2012; 6: 178-180.

13. Pallag A, Filip GA, Olteanu D, Clichici S, Baldea I, Jurca T, Micle O, Vicaş L, Marian E, Soriţău O, Cenariu M, Mureşan M, Equisetum arvense L. extract induces antibacterial activity and modulates oxidative stress, inflammation, and apoptosis in endothelial vascular cells exposed to hyperosmotic stress. Oxid Med Cell Longev., 2018; 2018: 1-14.

14. Agger WA, Siddiqui D, Lovrich SD, Callister SM, Borgert AJ, Merkitch KW, Mason TC, Baumgardner DJ, Burmester JK, Shukla SK, Welter JD, Stewart KS, Washburn MJ, Bailey HH, Epidemiologic factors and urogenital infections associated with preterm birth in a midwestern U.S. population. Obstet Gynecol., 2014; 124(5): 969-977.

15. Zarafu I, Pătrașcu B, Măruțescu L, Bleotu C, Limban C, Tatibouët A, Chifiriuc MC, Nuță DC, Ioniță P, Bioevaluation of the antimicrobial and antiproliferative potential of some derivatives of 3,5-dinitro-4methoxyamino-benzoic acid. Farmacia, 2020; 68(1): 8-14.

16. Leticia AJ, Patrick JW, Henry ER, Urinary tract infections in pregnancy, http://emedicine.medscape.com.

17. Moisa C, Margareta Vlad AM, Teușdea A, Cadar O, Hoaghia MA, Stan RL, Tăerel A, Jurca C, Vicaș LG, Randomized evaluation on the consumption of antibiotics in community pharmacies. Farmacia, 2018; 66(6): 1081-1090.
18. Schnarr J, Smaill F, Asymptomatic bacteriuria and symptomatic urinary tract infections in pregnancy. Eur J Clin Invest., 2008; 38(S2): 50-57.

19. Moore A, Doull M, Grad R, Groulx S, Pottie K, Tonelli M, Courage S, Garcia AJ, Thombs BD, Canadian Task Force on Preventive Health Care, Recommendations on screening for asymptomatic bacteriuria in pregnancy. CMAJ, 2018; 190(27): E823-E830.

20. Smaill FM, Vazquez JC, Antibiotics for asymptomatic bacteriuria in pregnancy. Cochrane Database Syst Rev., 2015; 8: CD000490.

21. Kazemier BM, Koningstein FN, Schneeberger C, Ott A, Bossuyt PM, de Miranda E, Vogelvang TE, Verhoeven CJ, Langenveld J, Woiski M, Oudijk MA, van der Ven JE, Vlegels MT, Kuiper PN, Feiertag N, Pajkrt E, de Groot CJ, Mol BW, Geerlings SE, Maternal and neonatal consequences of treated and untreated asymptomatic bacteriuria in pregnancy: a prospective cohort study with an embedded randomised controlled trial. Lancet Infect Dis., 2015; 15(11): 1324-1333.

22. CLSI. Performance Standards for Antimicrobial Susceptibility Testing. $28^{\text {th }}$ ed. CLSI supplement M100. Wayne, PA: Clinical and Laboratory Standards Institute; 2018.

23. Tambekar DH, Dhanorkar DV, Gulhane SR, Khandelwal VK, Dudhane MN, Antibacterial susceptibility of some urinary tract pathogens to commonly used antibiotics. Afr J Biotechnol., 2006; 5(17): 1562-1565.

24. Verma I, Avasthi K, Berry V, Urogenital infections as a risk factor for preterm labor: a hospital-based case-control study. J Obstet Gynaecol India., 2014; 64(4): 274-278.

25. Najafi MN, Rezaee $R$, Najafi NN, Mirzaee F, Burykina TI, Lupuliasa D, Arsene AL, Ghazanfarpour M, Herbal medicines against bacterial vaginosis in women of reproductive age: a systematic review. Farmacia, 2019; 67(6): 931-940.

26. Ailes EC, Summers AD, Tran EL, Gilboa SM, Arnold KE, Meaney-Delman D, Reefhuis J, Antibiotics dispensed to privately insured pregnant women with urinary tract infections - United States, 2014. MMWR Morb Mortal Wkly Rep., 2018; 67(1): 18-22.

27. Zaha DC, Kiss R, Hegedüs C, Gesztelyi R, Bombicz M, Muresan M, Pallag A, Zrinyi M, Pall D, Vesa $\mathrm{CM}$, Micle $\mathrm{O}$, Recent advances in investigation, prevention, and management of healthcare-associated infections (HAIs): Resistant multidrug strain colonization and its risk factors in an intensive care unit of a university hospital. Biomed Res Int., 2019; 2019: 1-9. 